This is the accepted manuscript of the article, which has been published in Comparative Education. 2018, 54(2), 132-158. https://doi.org/10.1080/03050068.2017.1348084

\title{
Quality Assurance and Evaluation through Brazilian lenses: an exploration into the validity of umbrella concepts
}

\author{
Vera G. Centeno - corresponding author \\ School of Education, University of Tampere, Finland \&
}

Centre for International and Comparative Education, Humboldt-Universität zu Berlin, Germany

Faculty of Education, Åkerlundinkatu 5, 33014 University of Tampere, Finland $+358503187837$

vera.centeno@uta.fi

Jaakko Kauko

Faculty of Education, University of Tampere, Finland

jaakko.kauko@uta.fi

\section{Helena Candido}

Faculty of Education, University of Tampere, Finland

\& University of Helsinki, Finland \& Federal University of Santa Catarina, Brazil

helena.candido@uta.fi

Vera Gorodski Centeno is a Post-doctoral Researcher at the University of Tampere and a Visiting Scholar at the Humboldt-Universität zu Berlin.

Jaakko Kauko is Associate Professor at the University of Tampere.

Helena Candido is a research fellow at the University of Tampere and a PhD student at the University of Helsinki and at the Federal University of Santa Catarina.

This work was supported by the Academy of Finland under Grant 273871. 


\title{
Quality Assurance and Evaluation through Brazilian lenses: an
} Exploration into the Validity of Umbrella Concepts

\author{
In our present research we address the question of whether it is valid to apply the \\ QAE (Quality Assurance and Evaluation) umbrella concept, which was \\ formulated to explain new phenomena in European educational governance, to \\ similar developments in Brazilian basic education. This led us to reflect on the \\ possible pitfalls and potential strengths of using umbrella concepts as analytical \\ tools. This article presents this exploration and its operationalization. We \\ confronted in-built assumptions in QAE with the contested, consensual and \\ creative use of the notion of quality in Brazilian basic education, and looked for \\ relationships. Our analysis shows that the Brazilian developments reiterate the \\ relationships concerning global interconnectivity, and challenges those pertaining \\ to conformity. We argue that the main risks of using umbrella concepts seem to \\ concern the re-production of understandings, which frequently leads to the \\ disregarding of deviation.
}

Keywords: Brazil, quality, basic education, umbrella concepts, evaluation, measuring, large-scale assessments, World Bank, SAEB, CAQI

The question of quality has been on the education agenda for decades. Internationally, prevailing quality-measurement practices (Simola et al. 2013) form a new 'mode of governance' by comparison (Nóvoa and Yariv-Mashal 2003), while nationally they are an addition to the traditional legislative, economic and ideological steering (Lundgren 1990). However, conceptualising such wide notions as quality or evaluation is rather challenging. Indeed, in research there is little consensus, for example, on methods or theory of evaluation (Grek, Lawn, Lingard and Varjo 2009; Vestman and Segerholm 2009; Dahler-Larsen 2012;). These slippery notions are difficult to define because as 
phenomena they are multidimensional social constructs. There is always more than one practical meaning for quality, for example, and quality itself hardly provides a basis for choosing among them. This is because the notion of quality splits into many dimensions - of how and what is considered quality, for whom and according to whom - that vary in line with specific socio-cultural and historical conditions. In addition, such slippery notions are difficult to problematize because they are inevitably related with 'distinct notions, each an element in its grammar' (on the 'structural grammar of equality', see Rae 1981, 18). Depending on the research perspective and context, these notions' content, as well as their claims, might greatly differ. This ambiguity is simultaneously the weakness and strength of such notions as quality and evaluation: their understanding might radically differ in antagonist circles, while their acceptability as an ideal is rather undisputed.

In research, one way of dealing with this definition problem is to create umbrella concepts that clearly refer to a specific procedure or set of practices, while simultaneously describing the phenomenon and conceptualising its general dynamic. One example of such umbrella concepts is that of Quality Assurance and Evaluation (QAE). The concept of QAE might refer to different practices with varied meanings (e.g. self-evaluation procedures, audits, inspections, assessments, benchmarks, indicators, governing and steering tools), and is used diversely according to research contexts (e.g. Trivellas \& Dargenidou 2008; Yamaguchi \& Tsukahara 2016). Still, in the education field, a group of scholars particularly coined QAE with the aim of enhancing understanding of educational discourses and policies that both define and develop quality in education and how it is measured. These authors framed, what we call here, the umbrella concept of QAE, because they share the view that quality is brought to light through measurement and comparison. Albeit approaches and 
terminology vary (Simola et al. 2009, Dahler-Larsen 2011), in their view, quality is no longer extraordinary but becoming "simply what can be expected... quality is conformity with standards" (Ozga et al. 2011b, 2). The notion of quality is being operationalized through standardised measurement, mainly manifested in large-scale assessments. Thereby, the QAE discourses, policies and practices, (re)create meanings, justify or motivate change, enhance or undermine political possibilities, reconfigure central-local relationships and redefine governments' responsibilities, among others dynamics. QAE emerges thus as a timely and promising umbrella concept, which bears the capacity to refer, describe and conceptualise some of today's most important educational phenomena and their dynamics.

Hence, a consistent use of QAE umbrella concept in educational research benefits largely from drawing on the view of the authors who framed it. In doing so in our present research, ${ }^{1}$ we were yet confronted with another line of reasoning: QAE has a particular intellectual affiliation. QAE was conceptualised by a group of authors working in and on European countries (e.g. Ozga 2009; Simola et al 2009). In fact, the European research project 'Fabricating Quality in Education' (Ozga et al. 2011a) used QAE as a framework to account for national and regional developments (e.g. Grek et al.

1 This article contributes to the analysis of educational developments in Brazil within the "Transnational Dynamics in Quality Assurance and Evaluation Politics of Basic Education in Brazil, China and Russia" project (Academy of Finland grant 273871). The main research objective is to explore how the intertwinement of local, sub-national, national, regional and global scales constructs the local dynamics in QAE politics, and thus shapes local learning environments in the case countries. 
2009) related to the broad phenomena of Europeanization and governance. ${ }^{2}$ This raises the question of whether QAE would serve as an umbrella concept through which to make sense of educational developments in contrasting sites. In tackling this question, we reflected on the possible pitfalls and the potential advantages of using such umbrella concepts as analytical tools. The aim in this article is to relate this reflection and its operationalization to the study of QAE and its manifestation in Brazilian basic education. In sharing our reflections and findings, we intend to contribute to current discussion about the challenges that research programmes are growingly facing in the global era.

\section{Problematizing the use of umbrella concepts}

The sociology of knowledge contests the rootedness of scientific knowledge. There are strong contingent relations between scholarly activity and its socio-political historical background. They are visible in the persistence of varying styles depending on the scholar's intellectual and geographical affiliation (Charle, Schriewer, and Wagner 2004). Educational knowledge is always produced with reference to particular educational experiences and contingent on particular dynamics, regardless of whether it is generated in international (e.g. Centeno 2014), national (e.g. Beech 2011) or subnational (e.g. Santos 2006) contexts.

\footnotetext{
${ }^{2}$ The Fabricating Quality in European Education (FabQ) project was funded as part of the 'Eurocores' programme of the European Science Foundation (ESF). It comprised linked national projects in Denmark, Finland, the UK (England and Scotland) and Sweden, and was co-ordinated by the Centre for Educational Sociology, University of Edinburgh (see the project website for further information: http://www.ces.ed.ac.uk/research/FabQ/index.htm).
} 
In fact, educational studies have influenced educational reforms on the ground as much as having been influenced by them (Nóvoa 2001), and research in Comparative Education (CE) has mirrored 'history' as much as having been inspired by it (see Cowen and Kazamias 2009, Cowen 2014a). If the production of educational knowledge is contingent, how can we engage with umbrella concepts such as QAE in comparative research?

These considerations notwithstanding, we have observed the emergence of new forms of scholarly knowledge (Wagner 2004). Comparative studies are no exception. Scholars have moved from plain comparisons to more elaborated research designs (Schriewer 1997, Nóvoa 2001), considering the relationship between globalisation and education through the prism of interrelated multiple developments (Schriewer and Martinez 2004) and cross-national policy spaces (Carney 2012), among other concepts. In spite of their diversity, recent approaches seem to share a quest to shed light on the constitution of global horizons of action and thinking, and their impact on today's educational life (see e.g. contributions in Resnik 2008, Cowen and Kazamias 2009, Schriewer 2009, Steiner-Khamsi and Waldow 2012). Global agendas (Dale 2000) and reform movements (Sahlberg 2011) are thought to shape educational phenomena. Umbrella concepts such as QAE seem particularly relevant from this perspective given their potential to reveal something about the 'context of the context' (Dale and Robertson 2012, 27). They facilitate the relating of seemingly unrelated policies and practices, thereby shedding light on educational processes in the current global era. How, then, could we use such umbrella concepts as QAE without falling into the trap of assuming their rootedness?

Our strategy is to place the problematisation of the umbrella concept concerned at the centre of the analysis. In reflecting about the possible pitfalls in the uncritical use 
of umbrella concepts, we found that our considerations resonated with critical reflections in our field of study, as well as in sociology and post-colonial studies.

\section{Turning pitfalls into strengths: an analysis of in-built assumptions in QAE}

In the field of $\mathrm{CE}$, discussions about how the latest educational developments should be understood have crystalized around two factions comprising those sympathetic to and sceptical about the world culture perspective, although multiple nuanced positions are to be found. The literature is extensive and well known (see e.g. Cowen 2014b) and it is of interest in this article only insofar as it has triggered critical questioning, some of which has inspired our own reflections.

Critics stress that world culture is based on taken-for-granted assumptions (Carney, Rappleye, and Silova 2012). Given that such assumptions are inferred rather than explicit, they imply a universal rather than a particular understanding (see Dale 2000). They constitute the basis of an all-encompassing conceptualisation that provides explanatory tools and explanations (Steiner-Khamsi 2012), but leaves no room for further elaboration, i.e. for refutation or exploration. They are critic-proof. Researchers using this framework tend to collect evidence that somehow corroborates initial generalisations, instead of testing them (see Schriewer 2012), and thereby risk reiterating and contributing to global policies. In other words, they risk mirroring their own object of study. Analogical criticism is useful in scrutinising empirically based umbrella concepts, such as QAE.

We elaborate our reflection under three nested pitfalls - implicit universalism, speculative generalisation and mirroring - and examined them in more detail below, first in relation to more general discussion and then as reflected in the QAE debate. For the analysis of the QAE debate, we draw mostly on the writings of the above-referred 
authors who introduce this umbrella concept in the field of education. In this analysis we sought to identify the in-built assumptions in QAE. Such assumptions are inherent in umbrella concepts of any kind, and if undetected they might implicitly channel research practice and establish a source of bias akin to encountering the pitfalls we herein discuss. On the other hand, if they are discerned and explicitly addressed they become research strengths in terms of allowing further exploration. We adopt the view in this article that the potential of $\mathrm{CE}$ research lies in fostering explanation by confronting established all-encompassing assumptions with contrasting analyses (Schriewer and Holmes 1990), so as to establish patterns of relationships (Green 2003) or generate new suggestions (Dale and Robertson 2012). In line with this view we consider it essential to scrutinise the in-built assumptions in QAE according to the three potential pitfalls. We aim to use this analysis to build awareness of how the uncritical application of umbrella concepts - in this case QAE - might channel biased understandings.

For the sake of clarity, and at the risk of being repetitive in terms of theoretical referencing, we opted in organising this exposition according to the three pitfalls, whose arguments are successively explained and applied to the analysis of the QAE umbrellaconcept. We present a systematisation of the identified in-build assumptions at the end of each section.

\section{Implicit universalism}

The first of these potential pitfalls is implicit universalism, in other words, the assumed adequacy of knowledge independent of space and time. This relates to questions of language and geography, and to how readership and research subjects are understood.

The use of language is perhaps the most striking example of how the production of knowledge is intellectually situated. In conducting comparative research, scholars have experienced and documented the situatedness of English-based conceptualisations 
in making sense of educational realities (e.g. Popkewitz 1993, xi and 13). Effectively, actors draw on a set of historically built semantic resources in imagining and interpreting the educational phenomena (Schriewer and Keiner 1992, Bourdieu 2002, Crossley and Tikly 2004). Knowledge is heavily locally-constructed (Anderson-Levitt 2012), and even travelling concepts that have a seemingly neutral one-size-fits all elaboration carry ideological ballast (Popkewitz 2005). Any conceptualisation reflects specific intellectual and socio-historical positioning, and might therefore impair other research perspectives, as well as the understanding of diverse educational developments.

The QAE umbrella concept reflects this situatedness. As the terminology clearly conveys, QAE relates to the New Public Management reforms that took hold in English-speaking countries in the 1980s/90s (Hood and Jackson 1991, Lane 1997, Barzelay 2001, Simola et al. 2009, Ozga and Grek 2012), and was implemented in different shades in different countries (e.g. de Boer, Enders, and Schimank 2008). These reforms advocated an approach based on management by results and evaluation, leading to new social practices in the governance of education, implying a more market-driven education system and business-like governance (Simola et al. 2009).

Geography still matters even in a globalised world. Scholars have deplored the geographic affiliation of the main globalisation theorists who "continuously operate within Eurocentric planetary consciousness' (Brah, Hickman, and Mac an Ghaill 1999, 16), thereby shaping the way in which the theories are constructed and opposed (Hesse 1999). In CE, as explained before, debates about the locality of concepts stress the risk of assuming a universal understanding of the world: concepts reveal the context of their production. Indeed, the historical trajectory of CE research shows how context and affiliation have significantly influenced its conceptual construction (see Kim 2014, 
Schriewer 2014, Cowen 2014b). The production of scholarly research is always contextbound (Wagner 2004).

There is considerable amount of research on how EU institutions and the OECD in particular contributes to the production and expansion of QAE through the collection of data and its use in world rankings (Carvalho 2012, Mulford 2002, Grek et al. 2009, Simola et al. 2013). Thereby, QAE sets standards and channels domestic policies. The OECD heads the global drive for performance assessment (Grek et al. 2009). Largescale assessments - however defined - were already in place in most European countries (Lundahl and Waldow 2009, Simola et al. 2009, country reports in the KNOWandPOL project). ${ }^{3}$ However, it was mainly in the aftermath of these reforms and of related activities in international organisations (IOs) that quality measurement became institutionalised in everyday education-policy discourse in the 2000s (Henry et al. 2001, Walters and Haahr 2005, Lawn and Grek 2012).

The question of whether the use of QAE in educational discussions and dispositions in Brazil might entail an implicit Eurocentric or English-based interpretation is of relevance to our study. The pitfall of universalism appears to apply particularly to the emergence of QAE. In this regard, the following in-built assumptions are identifiable: (i) the domestic emergence of QAE is related to the emergence of larger administrative and managerial reforms in the public sector in the 1990s, and (ii) is discernible in the renewed educational discourses through which quality was operationalized through its measurement in the 2000s; (iii) domestic QAE policies and practices are driven by OECD and EU activities.

\footnotetext{
${ }^{3}$ KNOWandPOL was a project funded by the European Union. As of 20 July 2009, the reports and further information are available on the project website (http://www.knowandpol.eu).
} 


\section{Speculative generalisation}

Closely connected with the first, the second potential pitfall concerns the speculative generalisations for which umbrella concepts prepare the ground and that convey overall descriptions of phenomena. Their application thus implies a certain characterisation of

the object of study. This, in turn, might channel the understanding of differently situated developments in that researchers could fall into the trap of conflating similar features across sites to match general interpretations. As noted above in relation to the debate on world culture, $\mathrm{CE}$ scholars have tended to discuss this in terms of complexity versus convergence. For the purposes of this study, however, it suffices to point out the risk that research findings would 'in some ways resemble photographs taken from highflying aircraft; the main features stand out, but much detail is lost, and the detail may be important' (Kingdom in Bennett 1991, 216). In a globalised world there is a good chance of falling into the trap of attributing too much explanatory power to perceived convergence.

Contributors to the QAE literature argue that the increasing use of QAE procedures has not led to convergence among European countries, which rather hold on to particular models according to their historical development (Simola et al. 2013). There is research evidence that the impact of international QAE policies is channelled through a domestic filtering process, in which they are entangled with or re-articulated through existing policies (Grek et al. 2009, Simola et al. 2009). Nonetheless, domestic terminologies vary along international lines: auditing, assessment, assurance, development, evaluation, inspection, management, monitoring, and planning for example (e.g. Kauko 2012). In the education context these accountability policies and practices translate into testing and indicators of performance (Ozga and Grek 2012). 
Given the purposes of our research, it is relevant to consider how the application of QAE could lead to the pitfall of generalisation by channelling the research to focus on similarities and analysing the findings accordingly. In the context of QAE this pitfall seems to be associated with its makeup, whereby another six in-built assumptions might be identified: (iv) QAE policies and practices are managerial in character, (v) hence education policies adopt managerial terminology; (vi) QAE is operationalized through performance assessments and indicators (vii) that are legitimised on accountability premises; (viii) international QAE policies are filtered in accordance with domestic traditions, (ix) however discourses follow the pathways mapped in the international framework.

\section{Mirroring}

The third potential pitfall confronting umbrella concepts in the global era is the mirror effect of their application (referred to as mirroring). The danger is that research reproduces what it scrutinises. Studies simultaneously describe and apply global interpretations, analyse and replicate global language, and investigate and exercise cross-national research. The thin line between researching and reproducing is striking.

For the purposes of this article, perhaps the most salient illustration of how educational research might mirror its own object of study concerns the role of experts, many of which are scholars, in the circulation of educational knowledge. Research on educational transfer has revealed a particular feature that is not bound to space and time, or to culture and policy: experts play a crucial role in enabling the transfer of knowledge. In other words, regardless of whether the focus is on earlier processes of schooling (Caruso 2010, Ressler 2010) or the current 'global architecture of education' (Jones 2007), on educational processes in China (Schulte 2008), Hispanic America (Roldán Vera and Schupp 2006), India (Tschurenev 2008), Mongolia (Steiner-Khamsi 
and Stolpe 2006) or in the OECD “rich man's club” (Mahon and McBride 2008, Centeno 2014), experts appear to function as the 'bridges' (Steiner-Khamsi and Stolpe 2006) that convey knowledge across sites.

Do scholars function as bridges that facilitate the 'international transfer of educational research modalities' (Crossley 2014, 21) in this globalised world? The research practice of analysing developments worldwide through the lenses of concepts created to address situated empirical development bears indeed some resemblance to the object of study we denominate as 'transfer'. Globalisation is challenging the construction of research programmes (Cowen 2000, Robertson and Dale 2008), as much as it is questioning research thinking: how far does the use of umbrella concepts such as QAE risk the reiteration of global policies?

In the context of Brazilian education this pitfall could relate to the analysis of the political possibilities that QAE triggers. In the European space, QAE provides 'the overarching rationale for data production in terms of both accountability and increased performance' (Grek et al. 2009, 5). Political alternatives other than accountability, managerialism and further performance assessment are not considered in the QAE debate. This might be understood as another (x) in-built assumption. If researchers use these political possibilities as lenses through which to study other developments, they might fall into the trap of feeding the exact neoliberal speak (the 'planetary vulgate', Bourdieu and Wacquant 2000) that they are referring to: they will certainly find what they are looking for, but will must probably also ignore anything else.

\section{Brazilian lenses: parallels within a contrastive framework}

Brazil is an interesting site in which to explore QAE as an umbrella concept. On the one hand, it unquestionably shows contrasting socio-cultural, economic-political and educational developments, thereby constituting a rich contrasting setting (see Schriewer 
1990, Popkewitz and Pereyra 1994, Badie and Hemet 2001). On the other hand, such exploration is only possible because of the evident parallels in Brazil with the QAE conceptualisation, making further examination of the in-built assumptions possible.

After more than twenty years of dictatorship, Brazil restored democracy at the end of the 1980s. The new Education Law was established in 1996, and further elaborated in a comprehensive National Education Plan in 2001 and 2014. There has been an avalanche of changes affecting all levels of educational provision in recent decades. Complex and encompassing large-scale assessments have accompanied, motivated or maintained these changes (Kauko et al. 2016).

The use of the term quality to address educational matters is recent, however. The Brazilian literature clearly illustrates the increasing attention being given to quality in basic education ('ensino fundamental'). ${ }^{4}$ For instance, in the course of our literature review (Candido, Kauko, and Centeno, submitted) we searched the Scielo database for relevant articles based on the keywords quality and education (using both 'educação' and 'ensino'). The number of selected articles concerning QAE in Brazilian basic education amounted to five in the 1990s, 73 in the 2000s and 91 in 2010-2014. This growing incidence mirrors the implementation (1990), reform (1995), consolidation

4 We are adopting the most common international classification of education, in which the basic level comprises primary or elementary education (first stage), and in some countries also lower-secondary education (second stage). This differentiates basic from pre-primary (early-childhood) education, and from secondary and higher education (International Standard Classification of Education, ISCED 2011, UNESCO). However, basic education in Brazil officially includes pre-primary ('educacao infantil') and secondary ('ensino médio') education, thereby corresponding to compulsory education. This means that alternatives to regular schooling are also included in basic education. Given the vast scope of basic education in Brazil, we have narrowed down our focus to regular elementary education ('ensino fundamental'). 
(2005) and enlargement (2013) of the Evaluation System of Basic Education (SAEB) ${ }^{5}$. SAEB was the first in a long sequence of policies to operationalize quality through large-scale assessments. It culminated in the new National Education Plan (PNE 20142024), which reiterates the goal in the 2007 Education Development Plan of reaching the OECD PISA mean score by 2021.

Brazil is currently vice chair of the PISA governing board, and the OECD describes the country as a model for improving education with the help of PISA (OECD n.d.): 'in terms of progress, you [Brazil] lead by example' (Gurría 2013). However, a common stance in Brazilian research is that the quality of education still does not come up to international standards (e.g. Oliveira and Araujo 2005, Durham 2010, Oliveira 2011). International observers classify the country as a developing economy (IMF $2015)$ with a poor public education system $\left(79^{\text {th }}\right.$ position in the 2013 education index,

5 From 1990 until 2005, the assessment suffered several methodological changes. The most significant concerned the adoption of the Item Response Theory in the design and analysis of the tests in 1995. In 2005 the SAEB started to combine two large-scale assessments. (i) The National Evaluation of Basic Education (ANEB) was the first assessment implemented. It aims 'to evaluate the quality, equity and efficiency of Brazilian education' (INEP n.d., para. 2). It assesses a sample of pupils from the $5^{\text {th }}, 9^{\text {th }}$ and $12^{\text {th }}$ grades, aiming at providing information to educational management. (ii) The National Evaluation of School Performance (ANRESC, 'Prova Brasil') has the goal of 'evaluating the quality of education in public schools' (INEP n.d., para. 3). It is applied to all $5^{\text {th }}$ and $9^{\text {th }}$ grade pupils in public schools and focuses on each school and municipality. Since 2013 the SAEB includes a third large-scale assessment. (iii) The National Evaluation of Literacy (ANA) targets the 'assessment of the literacy in the Portuguese language, mathematical literacy and the conditions of the Literacy Cycle offered in public networks' (INEP n.d., para. 4). The ANEB and the ANRESC are combined with the data from the School Census for the calculation of the Development Index of Basic Education (IDEB). The IDEB was created along with the 2007 Education Development Plan, and has a double aim of measuring the educational quality on all levels (from school to national), and of monitoring the national average educational achievement. 
UNDP). Parallels between the Brazilian situation and the phenomena captured in the QAE umbrella concept are easily recognisable.

However, the contrasting Brazilian development raises the question of how far the in-built assumptions in QAE resonate with it. To avoid falling into the trap of according the primacy of an a priori explanatory power to QAE we use the diagnosed pitfalls as the starting point of our analysis (Table 1). In other words, we focus on the emergence and makeup of QAE, as well as on the alternative possibilities it triggered. We adopt a social-historical analytical perspective and look at the "unique situations in time and space and the cultural resources available in these situations" (Hedstöm and Wittrock 2009, 8). This involves tracing the historical path that led to the present situation.

Table 1. An overview of the conceptual approach

In subjecting QAE to scrutiny, we find that evaluation is the operational part and that quality is the notional driving force. Our focus in this article is therefore on the use of the notion of quality. We track down the breakpoint that set in motion the process through which quality emerged as a valid political term to address educational issues. Path-dependence theories are stronger as analytical devices in such tasks (e.g. Pierson 2000). They incorporate a number of basic claims, such as that sequence and timing are fundamental in explaining policies and discourses, and that important developments are frequently the outcome of earlier breakpoints resulting from particular conjunctures (e.g. Baumgartner and Jones 2009, Capano 2009). It is essential to understand educational policy in its historical context to avoid the pitfall of universalism (see Nóvoa and Yariv-Mashal 2003). 
The historical view as a strategy also sheds light on the 'socio-logic' of the educational arena (Schriewer and Martinez 2004). We connect this idea in particular to the 'production of legitimacy' (Waldow 2012), which is one of the key features of QAE. We aim to enhance understanding of how interpretations of quality are built and legitimated. The terms employed to describe situations mirror the semantic resources available at a particular site (Schriewer and Harney 1999). Differences in the legitimacy of certain terms frequently represent the basis on which policies and programmes play out differently across sites (Lundahl and Waldow 2009). We aim to avoid the generalisation pitfall by focusing on legitimation. We therefore investigate the place of quality as a notion in the educational debate before and after its association with evaluation in basic-education policy, exploring changes in legitimate ways of talking, interpreting and contesting. In showing how policy formation is embedded in processes of legitimation we attest to its situatedness, thereby avoiding the pitfall.

The socio-historical approach facilitates the exploitation of political possibilities other than those prescribed in global views. Politics is a contingent activity (Palonen 2006), in which actors create possibilities by generating, (re)interpreting or dismissing political threads. It is essential in developing an understanding of how actors capitalise on existing situations, seize opportunities and create alternatives to mainstream trends to look behind the perceived convergence, and to reveal their room for action and positioning. In so doing, researchers avoid the mirroring effect in emphasising situated contingent developments instead of replicating ready-made conclusions. Hence, we shed light on a particular purposive discursive displacement occurring within the Brazilian political framework of QAE, and briefly illustrate a new political possibility it opened up. 
This exploration is part of a larger research project and therefore builds upon previous and current research. Elsewhere we have given a detailed historical account of the emergence of quality assessment in Brazil and the role of expert networks and IOs in this (Kauko et al. 2016). This inquiry was backed up with a systematic literature review (1990-2014), in which we synthesised the problematisations of quality in Brazilian basic education and its relation to QAE (Candido, Kauko, and Centeno submitted). The current investigation also benefits from previous studies (e.g. Centeno 2010), as well as from our first impressions from an on-going qualitative content analysis of the changing political arena in Brazil that is based on documentary and interview data $(n=21)$ gathered from key domestic collective and individual actors in $2015 .^{6}$

${ }^{6}$ The totality of the research data was collected during 2014-2016, and it included document analysis and literature reviews, as well as interviews and observations. The semi-structured interviews $(\mathrm{N}=90)$ were conducted from mid-2015 to beginning-2016, on the international $(n=7)$, national $(n=23)$, state $(n=21)$, municipal $(n=12)$, school $(n=27)$ levels. We privileged individual interviews, but at the request of the participants a few group interviews were also conducted ( $\mathrm{N}=101$ interviewees). We conducted interviews with representatives from the major international organisations active in Brazil, politicians and officials from government bodies at the three levels of policymaking (national, state and municipal levels) important national and state expert agencies and individuals, relevant national and state third-sector organisations, private organisations, school staff, parents and pupils. The computer-assisted (ATLAS.TI software) qualitative content analysis followed a mix of deductive (conceptdriven) and inductive (data-driven) logics (Schreier 2004). For this article we use the preliminary analysis of almost all national interviews. 


\section{Quality in Brazilian Basic Education: contested, consensual and creative}

Quality is a polysemous term in the Brazilian educational arena (Nardi, Schneider, and Rios 2014), its meaning varying according to the ideological and political stance of the actors (Gusmão 2010). More striking than the ambiguity of the notion is its ubiquity. Educational actors consensually perceive quality - however defined - as a legitimate semantic resource for describing or conceptualising educational matters. How did it become a constitutive notion on the Brazilian educational scene?

The next necessarily larger subsection constitutes the socio-historical contextualisation, illustrating the socio-logic and production of legitimacy in the educational arena. We chart the historically contested use of the term quality, and show how the contestation initially led to its disuse, but did not prevent its later political (mis)use. Its re-emergence in Brazil resonates with the in-built assumptions in the QAE umbrella concept.

Nevertheless, quality remained a contested notion. The following shorter subsection looks at the political breakpoint. We show how antagonist positions converged at the dawn of Brazilian democracy, and enabled the consensual use of quality in the educational arena. In some respects the makeup of the notion in Brazil challenges the in-built assumptions in QAE.

The legitimation of the notion of quality paved the way for other political possibilities in the QAE framework. In the last subsection we show how a particular purposefully discursive displacement provided civil-society actors with a renewed paradigm that made it possible to create, push forward and get their own ideas on the political agenda. In this respect the Brazilian case gives different insights than those proposed in the QAE umbrella concept, suggesting new avenues for studying QAE policies and practices. 


\section{Contested: the disuse and (mis)use of quality in Brazilian education}

General concern with education in Brazil was inconsequential at the turn of the 20th century. The 1920 census indicated that 72 per cent of the population over the age of five remained illiterate (Haddad and di Pierro 2006). The oligarchies channelled policy (Schneider 1971), and education was largely under the patronage of the Catholic Church (Romanelli 2007). A reform movement in the educational arena began to criticise the insufficient number and poor quality of schools in the 1920s, calling on the government to assume responsibility for public education (Peixoto 1995). From that time on, education was strongly tied to democratization, citizenship and the national identity.

In the following decade the previously united educational community rapidly drifted into conflicting factions known as the 'progressive educationists' and the 'conservators' (Nunes 1992, Romanelli 2007). ${ }^{7}$ These actors shaped educational discussion and policy. They recast the initially progressive/conservative stances into secular/religious perspectives, and then narrowed them down to the public/private divide. The notion of quality became entangled in these political and ideological battles.

\section{Disuse: democratisation and expansion - quantity at the expense of quality}

In a country in which education was the privilege of the few its democratisation became ideologically and politically associated with the determined expansion of school enrolment. The progressivists discursively constructed this argument in opposition to the maintenance of school quality (conservatives) and the improvement of teaching methods (Azanha 2004, see Fonseca 2009). The ensuing secular/religious debates resonated with the progressive/conservative stances. Whereas the former supported the

7 In this account we also adopt these commonly accepted historical antagonistic stances for the purpose of clarification. 
expansion of secular education, groups linked with the Catholic Church tried to maintain their influence, stressing the need for quality (Alvarenga 2003). Historically, these initial debates framed quality in opposition to quantity (Campos 2000).

How did this affect education policy? Brazilian governments attempted to reconcile these differences, the pendulum swinging according to their positioning. The revolutionary government (1934-1937) stressed its responsibility for education in the 1934 Constitution, but favoured the reform of secondary and higher education to the detriment of the regulation of Catholic schools and their activities (Romanelli 2007). However, the subsequent authoritarian government (1937-1945) reduced its educational responsibility to the "children and young people who lack[ed] the resources to pay for teaching in private educational institutions' (Art. 129) in the 1937 Constitution.

Later on, the democratic government (1946-1951) incorporated progressive ideas, such as responsibility for national education and compulsory free primary schooling, into the 1946 Constitution, but reaffirmed that publicly funded post-primary education was only available to those who did not have the financial resources to be taught in private institutions (Art. 168). The public/private issue was the basis of thirteen years of discussion around the elaboration of the first Educational Law. The 1961 Law presented a compromise solution (Saviani 1996) between the 1948 progressive draft (Freitag 1986) and the 1957 conservative proposals ('Lacerda's Substitutive').

Even if Brazil missed the opportunity to formulate a national system (Romanelli 2007), education clearly became a social imperative. The enrolment rate grew substantially even during the military dictatorship of 1964-1985 (Oliveira 2007). Economists gained a dominant position (Silva and Silva 2006), and the military governments adopted education as a strategy for social appeasement and economic 
growth (Fonseca 2009). They met social demands by means of extending compulsory schooling and creating second-chance schemes, for example. Nevertheless, most effort was put into adult education with a clear bias towards indoctrination (Haddad and Di Pierro 2000) and the transformation of secondary education into vocational training.

This short historical overview highlights four significant points. First, the actors historically constructed political positioning and discursive stances through binary opposition. Second, although Brazilian education followed the respective governments' ideological stances (Fonseca 2009), political compromise always happened, either by conciliating divergent positions or by meeting social demands for education (Saviani 1996). Third, despite the rapidly swinging political pendulum, the democratisation of education took shape in the concrete expansion of educational opportunities (Oliveira and Araujo 2005, Klein 2006, Oliveira 2007, Gouveia and Souza 2013). Fourth, in the course of this process, quantity and quality epitomised two antagonistic stances, and the Brazilian educational path has favoured, discursively as well as pragmatically, the former to the detriment of the latter (Campos 2000, Azanha 2004). This is arguably behind the general disuse of the notion of quality in the educational arena until the end of the military dictatorship.

(Mis)Use: educational management and assessment - quality back to the fore

A strong democratic movement progressively took hold in the 1980s, mainly stimulated by workers' strikes and walkouts. The strikers included numerous professors and teachers from all over the country (Alexander 2003). As a result, progressive ideas and proposals were brought into the political arena (Gouveia and Ferraz 2013).

Nonetheless, the notion of quality re-surfaced in the educational arena chiefly through the application of Total Quality Management (TQM) to both public administration and educational management. Although there were alerts coming from 
the educational community about the need to improve quality (Beisiegel 1975), ${ }^{8}$ it was essentially the perceived misuse of quality in TQM that re-fuelled the discussion.

Concomitantly, the first experiments were carried out on the use of assessment as a tool for educational planning.

After the dictatorship, Brazil was faced with economic adjustment (Wirth 1997), growing financial demands in the field of education (Campos and Haddad 2006), and calls from IOs for structural reforms. Governments adopted two strategies: the incorporation of TQM into educational programmes and the development of assessment tools.

TQM was widely disseminated throughout the industry and business sector in the 1980s as a powerful strategy to improve the production of quality goods and services (Longo 1996). In the international sphere, educational institutions began to adopt TQM in the 1990s for the purpose of administration and curriculum development (Winn and Green 1998). Apparently, Brazil was an early adopter in the global dissemination of managerial quality control as applied to education. However, in contrast to other early-adoption processes (Steiner-Khamsi and Ines 2006, 9-10), this one appeared to have been unsystematic and inconsequential. The Sarney Government (1985-90) designed a programme called The School of Total Quality. Gentili (1994) explains that the goal was to implement TQM in schools by fostering a unique transformative process in each one in order to improve Brazilian education as a whole: the school community (pupils, teachers, school staff, parents and others) and society were to cooperate in defining a 'pact for quality'. With the exception of Gentili's study,

8 Beisiegel was one of the few scholars writing about quality in the 1970s. The educational community came back to his ideas and texts in the 2000s (e.g. Gusmão 2010, Cabral and Di Giorgi 2002, Oliveira and Araujo 2005). Beisiegel re-published his 1975 article, together with others, in a 2006 compendium, noting that the ideas were still very relevant. 
it is difficult to find accounts detailing the impact of this programme, which arguably reflects its lack of impact on Brazilian educational planning as a whole.

Conversely, TQM had a strong impact on education-related discussions. Not only did it re-introduce the notion of quality into the debate, it also gave it a certain political legitimacy. The concept of total quality attracted a great deal of attention from all sectors. Policymakers, economists and sociologists identified parallels between the need for economic and educational restructuration, and saw TQM as a solution for the country's managerial problems (Longo 1996). Numerous publications reflected this interest, focusing on the relationship between education and work, and the effects of the total quality approach on education (Ricardo Filho 2010). Whereas economists and sociologists embraced TQM, educators strongly criticised it as a neo-liberal approach to education (Gentili and Silva 1994). Total quality became a fashionable and shared goal, which even engaged those who were against it (Enguita in Rodrigues 1995): it brought quality back to the fore.

Educational planning emerged as a fundamental issue in Brazil in the 1970s, i.e. before the introduction of TQM. Mass schooling raised concerns on the administrative level about issues ranging from the appropriateness of school materials to teacher training and curriculum organisation (Gatti 1987). Later on, the growing incidence of school dropout and retention rates became the main problems (Nardi, Schneider, and Rios 2014). Instead of introducing substantial reforms (Franco et al. 2007), states attempted to increase student flow by means of palliative measures such as automatic grade progression, the provision of acceleration classes, and the reorganisation of studies into cycles. These policies impaired the traditional indicators (Oliveira and Araujo 2005), leading state and municipal education secretaries to develop performance tests in the late 1970s as alternatives ways of gathering information (Gatti 1987). Some 
states received funding from the World Bank (IBRD/WB) for these programmes (e.g. EDURURAL), which influenced their formulation (Gatti, Vianna, and Davis 1991).

On the national level, the government started to develop pupil assessment in the framework of a loan agreement with the WB (1981-87) during the dictatorship (Kauko et al. 2016). The Sarney government (1987) began to design large-scale evaluations to provide information to state secretaries about learning difficulties (Gatti, Vianna, and Davis 1991, Horta Neto 2007). This led to the planning of the first nationwide Evaluation System of Public Education (SAEP). ${ }^{9}$ Despite the postponement of its national launch for financial reasons (Horta Neto 2007), SAEP prepared the ground for the 'first-generation assessment of basic education in Brazil' (Bonamino and Sousa 2012) that took place in the 1990s. These first initiatives facilitated later QAE practices (Kauko et al. 2016). The subsequent governments travelled down a path already trodden (Freitas 2004).

This confirms the in-built assumptions of the QAE umbrella concept in terms of its emergence. Although set against a contrasting social-historical backdrop and with a dissimilar stock of legitimate semantic resources, by and large, QAE surfaced in Brazil as it did in European countries in terms of public-sector managerial reforms, in connection with IOs, and in the light of a renewed educational discourse in which education quality became progressively associated with evaluation. The differences concerned situated specificities that do not call into question the relationships stressed in the umbrella concept.

9 It is interesting that Brazil was an early adopter not only of the application of managerial practices to education (TQM), but also of the institutionalisation of systematic performance-assessment schemes. This could be attributable to the long historical involvement of IOs in Brazilian education (see Centeno 2010; Kauko et al. 2016). 


\section{Consensual: the 1988 Constitution and the legitimation of the notion of quality}

The political appropriation of TQM and the further implementation of assessment tools triggered major debates and forced a repositioning in the educational arena. The educational community criticised both TQM and the assessment of neo-liberal practices embedded in the mercantilist vision (Gadotti 2013) for compromising the equality of educational opportunities and the democratisation of schooling (Campos and Haddad 2006). Again, the actors recast the notion of quality into two positions perceived as antagonistic.

How did the passage from a contested to a consensual use of quality in describing educational problems happen? As path-dependency theories explain, situations are frequently more sensitive to earlier than to on-going developments. The event that made possible the legitimation and use of the notion of quality in fact took place at the height of the criticism: the 1988 Constitution. It materialised at the intersection of the democratisation and expansion of education with the managerial approach to quality and assessment.

The 1988 Constitution mentions quality, as related to education, four times (Gusmão 2010). The first three times it appears in the form of a social right, related to the democratisation and expansion of education: twice with reference to the assurance of minimum patterns of quality in education and the third time connected with improvement in quality. In all three cases the right to quality education for all is expressed in terms of social justice and human rights (Freitas 2008).

The 1988 Constitution established a precedent for the consensual use of quality as a legitimate notion through which to address educational concerns: it recast quality within social argumentation. The Constitution was a milestone in Brazilian democracy: it was the outcome of a social-democratic movement and it was the first constitutional 
document to set out a list of social rights, of which education came first (Oliveira 2007). It also established a new political definition and social understanding of education, as a principle and a right (Cabral and Di Giorgi 2002). Later, this reframing made possible the discursive re-appropriation of the notion of quality into a legitimate argumentative framework (see the next section). Thus, in contrast to the in-built assumptions in the QAE umbrella concept, the Brazilian notion of education quality entered the legislation in the context of social practices. The legal framework took on social characteristics and terminology.

The fourth reference in the Constitution reflects Catholic as well as privatesector interests (Camargo in Gusmão 2010, 51). The same historical logic of compromise is followed in the framing of the overall text in a progressive tone, while safeguarding existing interests. The Constitution acknowledges the existence of privateeducation institutions, but seeks conciliation, regulating their functioning by putting public bodies in charge of evaluating and assuring their quality. As Freitas (2004) mentions, QAE practices emerge from the logical implementation of this disposition. How can the quality of private education be evaluated if that of public education is not evaluated? Against what standards should public bodies evaluate private education? How can the educational situations of more than 220.000 schools operating within 26 states, the federal district and over 5.000 municipal systems be evaluated without engaging in large-scale assessment? The 1988 Constitution provided the political rationale and legitimation for the development of such assessment. An apparent small detail clearly illustrates this. In 1990, the government implemented the previously planned Evaluation System of Public Education (SAEP). However, to comply with the directives of the 1988 Constitution, the name was changed to the Evaluation System of Basic Education (SAEB, Horta Neto 2007). In line with the in-built assumptions of the 
QAE umbrella concept, quality in education was operationalized through performance assessment, legitimated in an accountability framework.

The 1988 Constitution simultaneously cleared the way for QAE policies and the legitimation of the notion of quality, redefined as a socio-educational political project. This re-definition prepared the ground for a creative deviation: 'social quality' emerged from 'total quality'.

\section{Creative: 'social quality' and new political possibilities}

The ground was laid for the rapid development of QAE practices in the late 1980s. This political development pushed the educational community into creating new interpretations and new opportunities. Perhaps the most sui-generis of these was the discursive displacement from total to social quality.

The effects of the 1988 Constitution on the educational discourse only came to light later when the actors purposively recast the notion of quality within the paradigm of social rights, thereby legitimating its re-appropriation. The Brazilian literature charts this development. Scholars began to depict the history of schooling through the prism of quality (Oliveira and Araujo 2005). ${ }^{10}$ On the one hand, this historicisation shows how quality became a legitimate semantic resource for tackling educational challenges: depicting the evolution of a notion implies accepting its relevance. On the other hand, the renewed meta-narrative again reflects how the 'production of legitimacy' (Waldow

10 In their view, the historical problems reflect how the educational community understood education quality over time. For instance, the problems of school access in the 1940s and of school dropouts in the 1980s indicate that education quality meant, respectively, the expansion of school access and the regularization of student flow in those historical periods. Policymakers and civil-society actors (interview data) also embrace this renewed meta-narrative. 
2012) took place in the Brazilian educational arena. The rationale used later for banning the notion of quality was behind its re-appropriation. In Brazil, the rationale underpinning educational thinking is only legitimate if it is socially grounded.

Yet, a re-interpretation of the history of schooling as reflecting a constant quest for quality clearly hints at a quest for legitimacy. If we keep maintaining the simplistic dichotomy for the sake of clarity, it could be said that the arena was turned around: the same movement that constantly contested the use and misuse of quality in the past started advocating it. This re-positioning allowed the construction of a new paradigm: social quality.

What is social quality? Although the Ministry of Education (e.g. 2006) sometimes uses this notion, scholars, educators and civil society are the main drivers of its framing and usage. Initially framed explicitly in opposition to total quality (Campos and Haddad 2006, Gadotti 2013), it was rapidly appropriated as a counter-project of QAE policies (Azevedo 2007). The educational community perceives social quality as the democratic battle for inclusive and emancipatory education (Azevedo 2007). It projects a new vision of quality (Gadotti 2013) as a democratic condition (Dourado 2007) and a social right (Dourado n.d.), thereby representing a new parameter of the educational process (Dourado 2007, Cabral and Di Giorgi 2002). Examples of projects drawing on the notion of social quality are as comprehensive as its formulation. They include participatory processes in educational planning (Escola Cidadã/Citizen School, Azevedo 2007), new educational infrastructures in urban centres (CEUs, Padilha and Silva 2004) and the elaboration of municipal educational policies aimed at the emancipation of the popular classes (Flach 2005). As Bernhard Charlot states: social quality is 'typically Brazilian!' (Charlot in Gusmao 2010). 
Social quality implies purposeful discursive displacement in order to put other issues on the political agenda. Actors have been addressing long-term problems within the discursive frame of the 'assurance of minimum patterns of quality' set in the 1988 Constitution. These issues cover a variety of matters ranging from the teacher's career to social demands (Ramos 2014). Social quality mirrors the renewed semantic appropriation of quality, and this is creating new political possibilities.

The political success of including the Cost of Initial Quality Education per Student (CAQi), ${ }^{11}$ a civil society's 'proposal for the financing of public quality education for all' (Campanha 2010), in recent educational legislation, is an example of the new political possibilities the notion of social quality opens up. CAQi is an alternative method of calculating the educational budget that 'determines how much should be invested per student, per year to ensure a minimum standard of quality education' (Campanha 2010, 6). It is legally and discursively grounded in the 1988 Constitution's 'human right to quality public education' and its unfolding in later legislation (Campanha 2011, 9). It is anchored in the concept of 'social quality' and represents the concrete implementation of quality education (interview data). As a benchmark for the financing of public education, CAQi entails substantial augmentation of the Brazilian budget for education (Campanha 2010, 2011).

The most prominent social movement in Brazil, the Campanha Nacional pelo Direito à Educação (Campanha: the Brazilian Campaign for the Right to Education), ${ }^{12}$

11 For the purposes of this paper we focus only on CAQi, despite the existence of CAQ and other pupil-cost instruments. See the proposal website for a brief clarification of the differences between the two mechanisms, http://www.custoalunoqualidade.org.br.

12 The Campanha (Brazilian Campaign for the Right to Education, official translation, see Campanha 2010) was born in a small room in the headquarters of another civil-society actor, the Ação Educativa (interview data), the aim being to gather 'different political 
heralded the elaboration of CAQi in 2002, which within a couple of years became the flagship of the larger movement towards improving educational quality. Despite the criticism of this type of instrument, its technical features and efficacy (e.g. Oliveira and Araujo 2005), the Campanha seems justified in announcing CAQi as the result of a broad consensus built upon multiple 'alliances and partnerships', 'public policy advocacy' and 'social mobilization' (Campanha 2010, 49). After years of all-inclusive national workshops and studies, the Campanha signed a cooperation agreement with the Federal Education Council (CNE) in 2008. For the first time the CNE established a partnership with a civil-society movement (Campanha 2010). Two years later, the CNE endorsed the establishment of minimum patterns of basic-education quality in accordance with CAQi (Brasil 2010b). CAQi was debated, approved and further elaborated in major National Conferences of Education (CONEB 2008, CONAE 2010, 2014). Although it had only a marginal place in the first draft proposal of the National Education Plan 2011-2020 (Brasil 2010a), a year later an amendment brought it into the official framework (Brasil 2011). The current PNE 2014-2024 refers CAQi as a strategy to increase the public investments in public education (Brasil 2014).

Very recently, on 5 May 2016, the Ministry of Education established the National Evaluation System of Basic Education (SINAEB), the Board of which included Campanha representatives (Brasil 2016). The aim was to replace SAEB and use CAQi as one of the main education indicators (Brasil/MEC 2016). The Campanha

forces, to prioritize mobilization actions, political pressure and communication' (http://www.campanhaeducacao.org.br). Created in 1999, it is now a 'plural network of more than 200 teachers unions, social movements and civil society organizations that aim to grant every citizen its right to a quality public education' (Campanha 2010, 4). 
successfully put the CAQi on the Brazilian political agenda. ${ }^{13}$ This case is an illustration of a how actors seize opportunities and create unforeseen political possibilities in the framework of QAE practices.

A remark ought to be made. After the submission of this article, important events took place in Brazil. In the aftermath of a rapid and controversial change of government, a new administration took over (12 May 2016) and the SINAEB decree was repealed (25 August 2016). The educational community contested this political act severely, as well as other on-going political changes in education. While revising this article, we ask ourselves how to make sense of our findings. The current political situation did not originate in the education field, but rather steam from an encompassing political juncture. It is still too soon to assess any actual change in education. The Brazilian political situation is far from being settled and therefore of being resolved. A look at the Brazilian education history shows us that actors' coalitions and constellations change constantly according to political agendas. More often than not, these actors have an impact on the political agenda. Furthermore, this meets the premises of our theoretical framework: policy is a contingent activity.

\section{Conclusion: a focus on deviation rather than conformity}

As contingently created knowledge, umbrella concepts are susceptible to pitfalls such as implicit universalism, speculative generalisation and mirroring. However, as

13 Interview data shows that Campanha was in fact closely involved in the elaboration of the SINAEB. As an interviewee states: “...[For the] Campanha... the bigger movement...[it has] taken [it] a long time to construct that vision of the SINAEB... the National Evaluation System of Basic Education, that was a painful process [for the Campanha]...with a big effort..." (BR-NNGO). 
comprehensive analytical tools they also have the potential to foster explanations. This article has shown that awareness of the nature of the pitfalls could turn them into analytical strengths. The analyses illustrate how the identification and probing of the inbuilt assumptions of umbrella concepts makes it possible to trace relationships and to open up new avenues for research.

Do the in-built assumptions in QAE resonate with Brazilian developments? We have identified two clusters of relationships. The first of them concerns matching relationships. Borrowing Carney's expression, we name this cluster 'global interconnectivity' (2009). It reveals the impact of international networks and organisations, and of the construction of global visions and policies. It shows how educational discourse interconnects contrasting sites. Despite the contrasting political frameworks and socio-historical backdrops, the different purposes, timing and actors, QAE emerged, was legitimated and operationalized analogously in Brazil and Europe. Assumptions related to the emergence of QAE seem perfectly appropriate in explaining the development of QAE in Brazil, as do some of the assumptions about its makeup. The Brazilian specificities, namely timing and the actors involved, do not challenge the relationships established between the emergence of QAE, the launch of public-sector managerial reforms and IOs activities, together with the emergence of educational discourses in which educational quality became associated with evaluation. In the same vein, the relationships between the formulation of quality-in-education policies and the operationalization of performance assessments on the one hand, and the construction of a legitimacy frame based on accountability on the other, go hand-inhand with some of the assumptions concerning the constitution of QAE.

In fact, our exploration shows that the pitfalls connected with the uncritical use of umbrella concepts relate to the understanding of meanings, interpretations and 
possibilities. In this case it seems that implicit universalism would not have been a pitfall in our research, given that global interconnectivity facilitates the universal emergence and dissemination of ideas and practices. However, it would have been a pitfall if we had taken that emergence as a sign of conformity and had prematurely interpreted Brazilian developments in the light of European developments. This would have rebounded on the pitfall of speculative generalisation, insofar as we would have understood the parallels as plain similarities and ignored their actual meaning, which in turn would have encouraged us to mirror the possibilities stated in the QAE literature and to overlook the deviations.

The risks in the use of umbrella concepts seem to come down to the reproduction of understandings. The Brazilian developments challenge some of the inbuilt assumptions in QAE referring to its makeup and the political possibilities it might trigger. Although educational quality (re)emerged within the framework of managerial reforms, its first political articulation was in the realm of social rights. Even if the terms used to address quality-in-education are similar to the English QAE terminology (e.g. the assurance of minimum quality standards), they reflect a social-related discourse engaged in ensuring education rights to all Brazilians.

Therefore, even though QAE practices might be indiscriminately denominated as managerial, quality assurance in Brazil also has a social character in that it relates to the enactment of social rights. Therefore, we cannot say that the political terminology simply adopts the managerial terminology, as prescribed in the QAE umbrella concept. The discursive alternatives created within the QAE framework clearly reveal how the Brazilian discourse is strongly couched in socially related terminology. The best illustration of this is the renewed paradigm of 'social quality' that opposes the established mainstream framework. It is a purposive discursive deviation from 
managerial and assessment policies, which shows how actors are able to act within and around the QAE discursive frame, creating new possibilities that influence government practices. A political outcome of this paradigm is a new indicator for education funding elaborated by a social movement. Its inclusion in the education legislation and programmes (e.g. the PNE 2014-2024) shows how unforeseen alternatives may take root in the realm of QAE. In this vein, the substantiated in-built assumption that international QAE is filtered according to the traditions of individual countries gains in significance.

We refer to this second cluster of non-matching relationships as contextual creativity. It conveys an old and well-known idea in the field of CE: contextualisation is imperative in the understanding of educational developments. At the same time, it hints at a new research direction in which the focus is on deviation rather than conformity. The QAE framework brings new actors into the arena, triggering new power formations. An example of this is the emergence of a strong civil society in the Brazilian educational arena, whose activity is affecting the political agenda. This repositioning is on the move and the consequences are far from predictable. The analysis indicates that, although QAE policies and practices are pervasive in education, there is still much room for creative deviation (Badie 1992) and manoeuver. The apparent policy convergence is anything but policy closure (Carney and Bistra 2009).

We began this exploration with a plain question and challenging reflections. We end it with a plain answer and challenging observations. Yes, it is valid to use QAE to make sense of educational developments taking place in contrasting sites, such as Brazil and Europe. However, our exploration implies that more research into umbrella concepts is needed before they are uncritically taken into use, given that it might uncover deviation behind the conformity. We exemplified this by investigating whether 
QAE resonated with Brazilian developments, instead of identifying practices and policies that matched it. In other words, instead of seeing Brazilian basic education through QAE lenses, we analysed the umbrella QAE concept through Brazilian lenses.

\section{Acknowledgements}

This work was supported by the Academy of Finland under Grant 273871.We would like to thank Eneida Shiroma, Susanne Ress, Nadine Bernhard and Cristina Alarcón for their comments on an earlier draft of this article. 


\section{References}

Alexander, Robert J. 2003. A history of organized labor in Brazil. Westport, Connecticut, London: Praeger Piblishers, Greenwood Publishing Group.

Alvarenga, Lídia. 2003. "Política editorial e estado: estudo bibliométrico de artigos publicados na revista brasileira de estudos pedagógicos, 1944-74." Informação e Sociedade: Estudos, João Pessoa 13 (1):77-120.

Anderson-Levitt, K. M. (2012). Complicating the concept of culture. Comparative Education, 48(4), 441-45.

Azanha, José Mario Pires. 2004. "Democratização do ensino: vicissitudes da idéia no ensino paulista." Educação e Pesquisa 30:335-344.

Azevedo, José Clovis de. 2007. "Educação pública: o desafio da qualidade." Estudos Avançados 21 (60):7-26.

Badie, Bertrand, and Guy Hemet. 2001. La politique comparée. Paris: Armand Colin. Barzelay, Michael. 2001. The new public management : improving research and policy dialogue / Michael Barzelay, The Aaron Wildavsky forum for public policy ; 3. Berkeley, Calif. ; London : New York: University of California Press ; Russell Sage Foundation.

Baumgartner, Frank R., and Bryan D. Jones. 2009. Agendas and instability in American politics. Second ed, American politics and political economy series. Chicago: University of Chicago Press.

Beech, Jason. 2011. Global Panaceas, Local Realities: International Agencies and the Future of Education. Edited by Jürgen Schriewer, Komparatiszische Bibliothek. Frankfurter am Main: Peter Lang.

Beisiegel, Celso Rui. 1975. "A reforma e a qualidade do ensino." In Educação Brasileira: questões de atualidade, edited by Jorge Nagle, 40-56. São Paulo: EDART.

Beisiegel, Celso Rui. 2006. A qualidade do ensino na escola pública. Brasília: Liber Livro Editora Ltda.

Bennett, Colin J. 1991. "What Is Policy Convergence and What Causes It?" British Journal of Political Science 21 (2):215-233. 
Bonamino, Alicia, and Sandra Zákia Sousa. 2012. "Three generations of assessments of basic education in Brazil: interfaces with the curriculum in/of the school." Educação e Pesquisa 38 (2):373-388.

Bourdieu, Pierre. 2002. "Les conditions sociales de la circulation internationale des idées." Actes de la recherche en sciences sociales:3-8.

Bourdieu, Pierre, and Louis Wacquant. 2000. "La nouvelle vulgate planétaire." Le Monde Diplomatique.

Brah, Avtar , Mary J. Hickman, and Máirtín Mac an Ghaill, eds. 1999. Global futures : migration, environment, and globalization. Edited by Mary J. Hickman, Avtar Brah and Máirtín Mac an Ghaill. Vol. 53, Explorations in sociology. New York: Houndsmills, U.K: St. Martin's Press (Palgrave); Macmillan.

Brasil, Câmara dos Deputados. 2011. Comissão Especial destinada a proferis parece ao Projeto de Lei n. 8035 de 2010 do Poder Executivo que 'aprova o Plano Nacional de Educação para o decênio 2011-2020 e dá outras providências' (PL803510). 14/12/2011. Brasília, DF: Câmara dos Deputados. Accessed 23 April 2015. httpp://http://www.camara.gov.gov.pt/proposicoesWeb/fichadetramitacao?idPro posicao $=490116$.

Brasil, Câmara dos Deputados. 2014. Plano Nacional de Educação 2014-2024, Lei n. 13.005, de 25 de Junho de 2014, que aprova o Plano Nacional de Educação (PNE) e dá outras providências. Atualizada em 1/12/2014. Brasília, DF: Câmara dos Deputados, Centro de Documentação e Informação, Coordenação Edições Câmara

Brasil, Ministério da Educação. 2010a. Projeto de Lei, Aprova o Plano Nacional de Educação para o decênio 2011-2010, e dá outras providências. Brasília, DF: MEC. Accessed 23 April 2015. http://www.portal.mec.gov.br/index.php?option=com_docman\&view=download \&alias=7244-pne-projeto-lei-pdf\&category slu=dezembro-2010pdf\&Itemid=30192.

Brasil, Ministério da Educação, Conselho Nacional da Educação. 2010b. Parecer CNE/CEB n. 8/2010. Estabelece normas para aplicação do inciso IX do artigo 4o da Lei no 9.394/96 (LDB), que trata dos padrões mínimos de qualidade de ensino para a Educação Básica pública. In Diário Oficial da União, 5 Maio 2010. 
http://portal.mec.gov.br/index.php?option=com_docman\&view=download\&alia

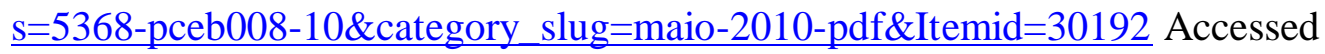
29 April 2015.

Brasil, Ministério da Educação, Instituto Nacional de Estudos e Pesquisas Educacionais Anísio Teixeira. 2016. Documento base preliminar para discussão, Sistema Nacional de Avaliação da Educação Básica. edited by Diretoria de Avaliação da Educação Básica (DAEB). Brasília, DF: DAEB/INEP. Sent by the INEP (10/05/2016), but available at:

https://avaliacaoeducacional.files.wordpress.com/2016/05/docpreliminarinep.pdf

Brasil, Ministério da Educação, Secretaria de Educação Básica. 2006. PRADIME:

Programa de Apoio aos Dirigentes Municiapis de Educação. Brasília, DF: MEC.

Brasil, Ministérios da Educação. 2016. Portaria n.369, de 5 de Maio de 2016, Institui o Sistema Nacional de Avaliação da Educação Básica - SINAEB. Brasília, DF: Diário oficial da União, 6 de Maio de 2016 (seçao 1, p. 26).

Brasil, Senado Federal. 1996. Lei de Diretrizes e Bases da Educação nacional, Lei n. 9.394 de 20 de Dezembro de 1996. Brasília, DF.

Cabral, Karina Melissa, and Cristiano Amaral Garboggini Di Giorgi. 2002. "O direito à qualidade da Educação Básica no Brasil: uma análise da legislação pertinente e das definições pedagógicas necessárias para uma demanda judicial." Educação 35 (1):116-128.

Campanha, Campanha Nacional pelo Direito à Educação. 2010. Cost of Initial Quality Education per Student, A Brazilian Campaign' proposal for the financing of public quality education for all. São Paulo: Campanha Nacional pelo Direito à Educação.

Campanha, Campanha Nacional pelo Direito à Educação. 2011. Educação pública de qualidade: quanto custa esse direito? São Paulo: Campanha Nacional pelo Direito à Educação.

Campos, Maria Malta. 2000. "A qualidade da educação em debate." In Cadernos do observatório: a educação brasileira na década de 90, edited by Campanha Nacional pelo Direito à Educação, 47-70. São Paulo: Campanha Nacional pelo Direito à Educação.

Campos, Maria Malta, and Sérgio Haddad. 2006. "O direito humano à educação escolar pública de qualidade." In A educação entre os direitos humanos, edited by 
Sérgio Haddad and Mariângela Graciano. Campinas e São Paulo: Autores Associados and Ação Educativa.

Candido, Helena H. D., Jaakko Kauko, and Vera G. Centeno. in preperation "Portraying quality assurance and evaluation in Brazil: an analysis of how quality is problematized in Brazilian basic education."

Capano, Giliberto. 2009. "Understanding Policy Change as an Epistemological and Theoretical Problem." Journal of Comparative Policy Analysis: Research and Practice 11 (1):7-31. doi: 10.1080/13876980802648284.

Carney, Stephen. 2009. "Negotiating policy in an age of globalization: Exploring educational "policyscapes" in Denmark, Nepal, and China." Comparative Education Review 53 (1):63-88.

Carney, Stephen. 2012. "Imagining globalisation: educational policyscapes." In World yearbook of education 2012: policy borrowing and lending in education, edited by Gita Steiner-Khamsi and Florian Waldow, 339-354. London and New York: Routledge.

Carney, Stephen, Jeremy Rappleye, and Iveta Silova. 2012. "Between Faith and Science:World Culture Theory and Comparative Education." Comparative Education Review 56 (3):366-393. doi: 10.1086/665708.

Caruso, Marcelo. 2010. Geist oder Mechanik Unterrichtsordnungen als kulturelle Konstruktionen in Preussen, Dänemark (Schleswig-Holstein) und Spanien 18001870. Edited by J. Schriewer, Comparative Education Series. Frankfurt am Main: Peter Lang.

Carvalho, Luís Miguel. 2012. "The Fabrications and Travels of a Knowledge-Policy Instrument." European Educational Research Journal 11 (2):172-188. doi: 10.2304/eerj.2012.11.2.172.

Centeno, Vera G. 2010. "Agency in establishing a transnational space: Brazilian interest in US-American educational assistance programs (1956-1974) " In World orders revisited, edited by Ulf Engel and Matthias Middell, 155-176. Leipzig: Leipziger Universitätsverlag

Centeno, Vera G. 2014. "Framing from above - fed from below - determined in interaction: a study on the OECD's Recurrent Education Policy Idea." PhD Dissertation, Centre for International and Comparative Education, Faculty of Humanities and Social Sciences, Humboldt-Universität zu Berlin, Germany. 
Charle, Christophe, J@ rgen Schriewer, and Peter Wagner. 2004. Transnational intellectual networks : forms of academic knowledge and the search for cultural identities. Frankfurt: Campus.

CONAE, Conferência Nacional de Educação. 2010. Construindo o sistema nacional articulado de educação: o plano nacional de educação, diretrizes e estratégias de ação. edited by Comissão Organizadora Nacional da CONAE. Brasília, DF: MEC. Accessed 18 August 2015, http://www.pne.mec.gov.br/images/pdf/CONAE2010_doc_final.pdf.

CONAE, Conferência Nacional de Educação. 2014. O PNE na articulação do sistema nacional de educação: participação popular, cooperação, federativa e regime de colaboração. edited by Fundo Nacional de Educação (FNE). Brasília, DF: MEC. Accessed 18 August 2015, http://www.fne.mec.gov.br/images/doc/DocumentoFina240415.pdf.

CONEB, Conferência Nacional de Educação Básica. 2008. PRADIME: Programa de Apoio aos Dirigentes Municiapis de Educação. Brasília, DF: MEC. Accessed 18 August 2015, http://www.conae.mec.gov.br/images/stories/pdf/doc_finalconeb.pdf.

Cowen, Robert. 2000. "Comparing futures or comparing pasts?" Comparative Education 36 (3):333-347.

Cowen, Robert. 2014a. "Comparative education: stones, silences, and siren songs." Comparative Education 50 (1):3-14. doi: 10.1080/03050068.2013.871834.

Cowen, Robert. 2014b. "Ways of knowing, outcomes and 'comparative education': be careful what you pray for." Comparative Education 50 (3):282-301. doi: 10.1080/03050068.2014.921370.

Crossley, Michael. 2014. "Global league tables, big data and the international transfer of educational research modalities." Comparative Education 50 (1):15-26. doi: 10.1080/03050068.2013.871438.

Crossley, Michael, and Leon Tikly. 2004. "Postcolonial Perspectives and Comparative and International Research in Education: A Critical Introduction." Comparative Education 40 (2):147-156.

Dahler-Larsen, Peter. 2011. "Afterword." In Fabricating quality in education: data and governance in Europe, edited by Jennifer Ozga, Peter Dahler-Larsen, Christina Segerholm and Hannu Simola, 151-159. London; New York: Routledge.

Dahler-Larsen, P. (2012b). The Evaluation Society. Stanford: Stanford University Press. 
Dale, Roger. 2000. "Globalization and Education: demonstrating a 'common world educational culture' or locating a 'globally structured educational agenda'?" Educational Theory 50 (4):427-448. doi: 10.1111/j.1741-5446.2000.00427.x.

Dale, Roger, and Susan L. Robertson. 2012. "Toward a critical grammar of education policy movements." In World yearbook of education 2012: Policy borrowing and lending in education, edited by Gita Steiner-Khamsi and Florian Waldow. London and New York: Routledge.

de Boer, H. F., J. Enders, and U. Schimank. 2008. "Comparing higher education governance systems in four European countries." In Governance and performance of education systems, edited by N. C. Soguel and P. Jaccard, 35-54. Dordrecht: Springer.

Dourado, Luiz Fernandes. 2007. "Políticas e gestão da educação básica no Brasil: limites e perspectivas." Educação \& Sociedade 28 (100):921-946.

Dourado, Luiz Fernandes. n.d. A qualidade da educação: conceitos e definições. MEC/INEP. Accessed 27 January 2016 http://escoladegestores.virtual.ufc.br/PDF/sala4_leitura2.pdf.

Durham, Eunice Ribeiro. 2010. "A política educacional do governo Fernando Henrique Cardoso: uma visão comparada." Novos Estudos - CEBRAP:153-179.

Flach, Simone de Fátima. 2005. "Avanços e limites na implementação da qualidade social da educação na política educacional de ponta grossa, gestão 2001-2004." Master Thesis, Políticas e Gestão da Educação, Program de Pós-graduação em Educação, Universidade Federal do Paraná.

Fonseca, Marília. 2009. "Políticas públicas para a qualidade da educação brasileira: entre o utilitarismo econômico e a responsabilidade social." Cadernos CEDES 29:153-177.

Franco, Creso, Isabel Ortigão, Ângela Albernaz, Alicia Bonamino, Glauco Aguiar, Fátima Alves, and Natália Sátyro. 2007. "Qualidade e eqüidade em educação: reconsiderando o significado de 'fatores intra-escolares'." Ensaio: Avaliação e Políticas Públicas em Educação 15 (55):277-298.

Freitag, Barbara. 1986. Escola, Estado e sociedade. São Paulo: Cortez \& Moraes. Freitas, Dirce Nei Teixeira de. 2004. "Avaliação da educação básica e ação normativa federal." Cadernos de Pesquisa 34 (123):663-689.

Freitas, Dirce Nei Teixeira de. 2008. "Ação reguladora da União e qualidade do ensino obrigatório (Brasil, 1988-2007)." Educar (31):33-51. 
Gadotti, Moacir. 2013. "Qualidade na educação: uma nova abordagem." Congresso de Educação Básica: Qualidade na Aprendizagem, Florianópolis, SC, Brasil.

Gatti, Bernardette A. 1987. "Testes e avaliações do ensino no Brasil." Educação e Seleção 16:33-41.

Gatti, Bernardette A., Heraldo Marelim Vianna, and Cláudia Davis. 1991. "Problemas e impasses da avaliação de projetos e sistemas educacionais: dois casos brasileiros." Estudos em Avaliação Educacional (4):7-27.

Gentili, Pablo A. A. 1994. "O discurso da 'qualidade' como nova retórica conservadora no campo educacional." In Neoliberalismo, qualidade total e educação: visões críticas, edited by Pablo A. A. Gentili and Tomaz Tadeu da Silva, 204. Petropólis: Vozes.

Gentili, Pablo A. A., and Tomaz Tadeu da Silva. 1994. Neoliberalismo, qualidade total e educação: visões críticas. Petropólis: Vozes.

Gouveia, Andréa Barbosa, and Marcos Alexandre dos Santos Ferraz. 2013. "Sindicalismo docente e política educacional: tensões e composições de interesses corporativos e qualidade da educação." Educar em Revista (48):111129.

Gouveia, Andréa Barbosa, and Ângelo Ricardo de Souza. 2013. "Efetividade da poítica para o ensino fundamental em municípios Brasileiros." Cadernos Pesquisa 43 (150):836-855.

Green, Andy. 2003. "Education, Globalisation and the Role of Comparative Research." London Review of Education 1 (2):83-97. doi: 10.1080/1474846032000098464.

Grek, S., M. Lawn, B. Lingard, J. Ozga, R. Rinne, C. Segerholm, and H. Simola. 2009. "National policy brokering and the construction of the European Education Space in England, Sweden, Finland and Scotland." Comparative Education 45 (1):5.

Grek S., Lawn, M., Lingard, B. \& Varjo J. (2009). North by northwest: Quality Assurance and Evaluation Processes in European Education. Journal of Education Policy 24 (2), 121-133.

Gurría, Angel. 2013. "Brazil becomes an Associate in the PISA Governing Board, Remarks by Angel Gurría, OECD Secretary-General, delivered at the signing ceremony 22 October 2013, Brasília, Brazil." OECD Accessed 8 February 2016. http://www.oecd.org/edu/brazil-becomes-an-associate-in-the-pisa-... 
Gusmão, Joana Buarque de. 2010. "Qualidade da educação no Brasil: consenso e diversidade de significados." Master Thesis, Faculdade de Educação, Universidade de São Paulo.

Gusmão, Joana Buarque de. 2013. "A construção da noção de qualidade da educação [Construction of the concept of quality of education]." Ensaio: Avaliação de Políticas Públicas Educacionais 94 (236):299-322.

Haddad, Sérgio, and Maria Clara Di Pierro. 2000. "Escolarização de jovens e adultos." Revista Brasileira de Educação 014:108-130.

Hedstöm, Peter, and Björn Wittrock. 2009. "Introduction: frontiers of sociology." In Frontiers of sociology, edited by Peter Hedstöm and Björn Wittrock, 1-14. Leiden, Boston: Brill.

Henry, Miriam, Bob Lingard, Fazal Rizvi, and Sandra Taylor. 2001. The OECD, globalisation and education policy. Edited by International Association of Universities, Issues in higher education. Amsterdam ; Oxford: Pergamon.

Hesse, Barnor. 1999. "Reviewing the Western spectacle: reflexive globalization through the black diaspora." In Global futures : migration, environment, and globalization, edited by Avtar Brah, Mary J. Hickman and Máirtín Mac an Ghaill. New York : Houndsmills, U.K: St. Martin's Press (Palgrave); Macmillan. Hood, Christopher, and Michael Jackson. 1991. Administrative argument Aldershot, Hants, England ; Brookfield, Vt., USA: Dartmouth Pub. Co.

Horta Neto, João Luz. 2007. "Um olhar retrospectivo sobre a avaliação externa no Brasil: das primeiras medições em educação até ao SAEB de 2005." Revista Iberoamericana de Educación 42 (5):1-13.

IMF. 2015. World Economic Outlook, April 2015: Uneven Growth, Short- and LongTerm Factors. In World Economic and Financial Surveys, edited by IMF. Washington, DC: IMF.

Jones, Phillip W. 2007. "Global governance, social policy and multilateral education." Comparative Education 43 (3):321-323.

Kauko, Jaakko. 2012. "The power of normative coordination in the Bologna process: how universities learned to stop worrying and to love quality assurance." Journal of the European Higher Education Area (4):23-40.

Kauko, Jaakko, Vera G. Centeno, Helena H. D. Candido, Eneida Shiroma, and Anni Klutas. 2016. "The emergence of quality assessment in Brazilian basic education." European Educational Research Journal 15(5): 558-579. 
Kazamias, A. M., R. Cowen, and A. M. Kazamias. 2009. International handbook of comparative. Dordrecht: Springer.

Kim, Terri. 2014. "The intellect, mobility and epistemic positioning in doing comparisons and comparative education." Comparative Education 50 (1):58-72. doi: 10.1080/03050068.2013.874237.

Klein, Ruben. 2006. "Como está a educação no Brasil? O que fazer?" Ensaio: Avaliação de Políticas Públicas Educacionais 14 (51):139-172.

Lane, Jan-Erik, ed. 1997. Public sector reform : rationale, trends and problems / edited by Jan-Erik Lane. London, Thousand Oaks, Calif: Sage Publications.

Lawn, M., and S. Grek. 2012. Europeanizing education. Governing a new policy space. Vol. null, null.

Longo, Rose Mary Juliano. 1996. "Gestão da Qualidade: Evolução Histórica, Conceitos Básicos e Aplicação na Educação, Texto para discussão n.397." Gestão da Qualidade na Educação: Em Busca da Excelência, Centro de Tecnologia de Gestão Educacional, SENAC — SP, 9-10 Novembro 1995.

Lundahl, Christian, and Florian Waldow. 2009. "Standardisation and 'quick languages': the shape-shifting of standardised measurement of pupil achievement in Sweden and Germany." Comparative education 45 (3):365-385.

Lundgren, Ulf P. 1990. "Evaluation as policymaking, decentralisation, evaluation." In Evaluation as policymaking : introducing evaluation into a national decentralised educational system, edited by Marit Granheim, Maurice Kogan and Ulf P. Lundgren, 256 p. London: Kingsley.

Mahon, Rianne, and Stephen McBride, eds. 2008. The OECD and Transnational Governance: UBC Press.

Mulford, Bill. 2002. "Sorting the Wheat from the Chaff - Knowledge and Skills for Life: first results from OECD's PISA 2000." European Journal of Education 37 (2):211-221. doi: 10.1111/1467-3435.00103.

Nardi, Elton Luiz, Marilda Pasqual Schneider, and Mônica Piccione Gomes Rios. 2014. "Qualidade na educação básica: ações e estratégias dinamizadoras." Educação e Realidade 39 (2):359-390.

Nóvoa, António. 2001. "Commentaires sur la place de la recherche pédagogique." Revue française de pédagogie:101-105. 
Nóvoa, António, and Tali Yariv-Mashal. 2003. "Comparative Research in Education: a mode of governance or a historical journey?" Comparative Education 39 (4):423-438. doi: 10.1080/0305006032000162002.

Nunes, Clarice. 1992. "História da educação brasileira: novas abordagens de velhos objetos." Teoria \& Educação (6):151-182.

OECD. n.d. "The OECD's contribution on education to the post-2015 framework: PISA for development." OECD. https://http://www.oecd.org/pisa/aboutpisa/POST2015_paper_education_20_Feb.pdf.

Oliveira, Dalila Andrade. 2011. "Das políticas de governo à política de estado: reflexões sobre a atual agenda educacional brasileira." Educação \& Sociedade 32 (115):323-337.

Oliveira, Romualdo Portela de. 2007. "Da universalização do ensino fundamental ao desafio da qualidade: uma análise histórica " Educação \& Sociedade 28 (100):661-690.

Oliveira, Romualdo Portela de, and Gilda Cardoso de Araujo. 2005. "Qualidade do ensino: uma nova dimensão da luta pelo direito à educação." Revista Brasileira de Educação:5-23.

Ozga, Jennifer, Peter Dahler-Larsen, Christina Segerholm, and Hannu Simola. 2011a. Fabricating quality in education: data and governance in Europe. London; New York: Routledge.

Ozga, Jennifer, Peter Dahler-Larsen, Christina Segerholm, and Hannu Simola. 2011b. "Introduction " In Fabricating quality in education: data and governance in Europe, edited by Jennifer Ozga, Peter Dahler-Larsen, Christina Segerholm and Hannu Simola, 1-8. London; New York: Routledge.

Ozga, Jennifer, and Sotiria Grek. 2012. "Governing through leraning. School selfevaluation and knowledge-based regulatory tool." Recherches sociologiques et anthopologiques 43 (2):35-52.

Padilha, Paulo Roberto, and Roberto da Silva, eds. 2004. Educação com qualidade social: a experiência dos CEUs de São Paulo. São Paulo: Instituto Paulo Freire, Secretaria Municipal de Educação, Cortez Editora.

Palonen, Kari. 2006. The struggle with time. A conceptual history of 'politics' as an activity. Hamburg: Verlag Münster.

Peixoto, Anna Maria Casassanta. 1995. " L’influence des idées étrangères sur l'enseignement au Brésil." Histoire de l'Education 65 (1):3-26. 
Pierson, Paul. 2000. "Increasing Returns, Path Dependence, and the Study of Politics." The American Political Science Review 94 (2):251-267. doi: 10.2307/2586011.

Popkewitz, T.S. 1993. Changing Patterns of Power: Social Regulation and Teacher Education Reform: State University of New York Press.

Popkewitz, Thomas S., and Miguel A. Pereyra. 1994. "Estudio comparado de las práticas contemporáneas de reforma de la formación del professorado en ocho países: configuración de la problématica y construcción de una metodologia comparativa." In Modelos de poder y regulación social en Pedagogia, edited by Thomas S. Popkewitz. Barcelon: Ediciones Pomares-Corredor.

Popkewitz, T.S. (2005): Inventing the Modern Self and John Dewey. Modernism and the travelling of pragmatism in education - An introduction. In Popkewitz, T.S (Ed) (2008): Inventing the Modern Self and John Dewey. Modernism and the travelling of pragmatism in education. (p.3-38). New York: Palgrave

Rae, Douglas W. 1981. Equalities. Cambridge, Mass.: Harvard University Press.

Resnik, Julia, ed. 2008. The production of educational knowldge in the global era. Rotterdam/Taipei: Sense Publishers.

Ressler, Patrick. 2010. Nonprofit-Marketing im Schulbereich. Britische Schulgesellschaften und der Erfolg des Bell-Lancaster-Systems der Schulorganisation im 19. Jahrhundert [Nonprofit marketing in education. British school societies and the success of the Bell-Lancaster system in school organization in the 19th century]. Frankfurt/M: Peter Lang.

Ricardo Filho, Geraldo Sabino. 2010. "O discurso sobre as políticas educacionais: coesões e ramificações dos especialistas em educação (1990-2007)." PhD Thesis, Faculdade de Educação, Universidade de São Paulo.

Robertson, Susan, and Roger Dale. 2008. "Researching education in a globalising era." In The production of educational knowledge in the global era, edited by Julia Resnik, 19-32. Rotterdam/Taipei: Sense Publishers.

Rodrigues, José. 1995. "Neoliberalismo, qualidade total e educação." Pro-Posições 6 (3[18]):115-118.

Roldán Vera, Eugenia, and Thomas Schupp. 2006. "Network analysis in comparative social sciences." Comparative Education 42 (3):405-429. doi: $10.1080 / 03050060600876723$.

Romanelli, Otaíza de Oliveira. 2007. História da educação no Brasil (1930-1973). 31st ed. Petrópolis, Brasil: Editora Vozes. Original edition, 1978. 
Sahlberg, Pasi. 2011. "The Fourth Way of Finland." Journal of Educational Change 12 (2):173-185. doi: 10.1007/s10833-011-9157-y.

Santos, Boaventura de Sousa. 2006. "Globalizations." Theory, Culture \& Society 23 (23):393-399.

Saviani, Dermeval. 1996. Política e educação no Brasil. 3rd. ed. Campinas: Cortez/Autores Associados. Original edition, 1987.

Schneider, Ronald M. 1971. Emergence of a 'modernizing authoritarian regime, $1964-$ 1970. New York and London: Columbia University Press.

Schreier, Margrit. 2014. "Qualitative Content Analysis." In The SAGE Handbook of Qualitative Data Analysis, edited by Uwe Flick, 170-183. London, UK: Sage Publications Ltd.

Schriewer, Juergen. 2009. Discourse Formation in Comparative Education. Edited by Jürgen Schriewer. 3rd. ed. Vol. 10, Comparative studies series. Frankfurt am Main: Peter Lang.

Schriewer, Juergen, and Klaus Harney. 1999. "Beruflichkeit versus Culture technique: Pour une sociogenèse de la sémantique du travail en France et en Allemagne." In Le Travail et la Nation. Histoire croisée de la France et de l'Allemagne à l'horizon européen, edited by Claude Didry, Peter Wagner and Bénédicte Zimmermann, 107-146. Paris: Maison des Sciences de l'Homme.

Schriewer, Jürgen. 1990. "The method of comparison and the need for externalization: methodological criteria and sociological concepts." In Theories and methods in comparative education, edited by Jürgen Schriewer and Brian Holmes. Frankfurt am Main; New York: P. Lang.

Schriewer, Jürgen. 1997. "L'éducation comparée : mise en perspective historique d'un champ de recherche." Revue française de pédagogie (121):9-27.

Schriewer, Jürgen. 2012. "EDITORIAL: Meaning constellations in the world society." Comparative Education 48 (4):411-422. doi: 10.1080/03050068.2012.737233.

Schriewer, Jürgen. 2014. "Neither orthodoxy nor randomness: differing logics of conducting comparative and international studies in education." Comparative Education 50 (1):84-101. doi: 10.1080/03050068.2014.883745.

Schriewer, Jürgen, and Brian Holmes. 1990. Theories and methods in comparative education. Frankfurt am Main; New York: P. Lang. 
Schriewer, Jürgen, and Edwin Keiner. 1992. "Communication Patterns and Intellectual Traditions in Educational Sciences: France and Germany." Comparative Education Review 36 (1):25-51.

Schriewer, Jürgen, and Carlos Martines. 2004. "Constructions of Internationality in Education." In The Global Politics of Educational Borrowing and Lending, edited by Gita Steiner-Khamsi, 29-53. New York: Teachers College Press.

Schulte, Barbara. 2008. "'Zur Rettung des Landes" : Bildung und Beruf im China der Republikzeit."

Silva, Ítalo Batista da, and Ed Francklin da Silva. 2006. "Aspectos históricos dos planos nacionais de educação do Brasil: da décade de 30 à de 80." Holos 22:19-25.

Simola, H., R. Rinne, J. Varjo, H. Pitkänen, and J. Kauko. 2009. "Quality assurance and evaluation (QAE) in Finnish compulsory schooling: a national model or just unintended effects of radical decentralisation?" Journal of Education Policy 24 (2):163.

Simola, Hannu, Risto Rinne, Janne Varjo, and Jaakko Kauko. 2013. "The paradox of the education race: how to win the ranking game by sailing to headwind." Journal of Education Policy 28 (5):612-633. doi: 10.1080/02680939.2012.758832.

Steiner-Khamsi, Gita. 2012. "The global/local nexus in comparative policy studies: analysing the triple bonus system in Mongolia over time." Comparative Education 48 (4):455-471. doi: 10.1080/03050068.2012.681120.

Steiner-Khamsi, Gita, and Stolpe Ines. 2006. "Educational import local encounters with global forces in Mongolia." Palgrave Macmillan.

Steiner-Khamsi, Gita, and Ines Stolpe. 2006. Educational import local encounters with global forces in Mongolia. New York: Palgrave Macmillan.

Steiner-Khamsi, Gita, and Florian Waldow. 2012. World yearbook of education 2012: Policy borrowing and lending in education. London and New York: Routledge.

Trivellas, P \& Dargenidou D (2008) Organisational culture, job satisfaction and higher education service quality: The case of Technological Educational Institute of Larissa. The TQM journal 21 (4), 382-399.

Tschurenev, Jana. 2008. "Diffusing useful knowledge: the monitorial system of education in Madras, London and Bengal, 1789-1840." Paedagogica Historica 44 (3):245-264. doi: 10.1080/00309230802041526. 
Vestman, O. \& Segerhom, C. (2009). Dialogue, dileberation and democracy in educational evaluation. In The SAGE International Handbook of Educational Evaluation. Thousand Oaks: Sage, 465-482.

Yamaguchi, AM \& Tsukahara, S (2016) Quality assurance and evaluation system in japanese higher education. Avaliação (Campinas) 21 (1), 71-87.

Wagner, Peter. 2004. "Varieties of interpretation of modernity: on national traditions in sociology and the social sciences." In Transnational intellectual networks : forms of academic knowledge and the search for cultural identities, edited by Christophe Charle, Jürgen Schriewer and Peter Wagner, 558 p. Frankfurt: Campus.

Waldow, Florian. 2012. "Standardisation and legitimacy: two central concepts in research on educational borrowing and lending." In World yearbook of education 2012: Policy borrowing and lending in education, edited by Gita Steiner-Khamsi and Florian Waldow. London and New York: Routledge.

Walters, William, and Jens Henrik Haahr. 2005. Governing Europe Discourse, Governmentality and European Integration. USA and Canada: Routledge.

Winn, Robert C., and Robert S. Green. 1998. "Applying Total Quality Management to the Educational Process." International Journal of Engineering Education 14 (1):24-29.

Wirth, John D. 1997. "Reviewed work: The means of our salvation: public education in Brazil, 1930-1995 by David N. Plank." American Journal of Education 105 (4):484-488. 